\title{
AOR
}

Selected Papers of \#AolR2021:

The 22nd Annual Conference of the

Association of Internet Researchers

Virtual Event / 13-16 Oct 2021

\section{TOWARDS CIVIC PARTICIPATION IN THE DATAFIED SOCIETY: CAN CITIZEN ASSEMBLIES DEMOCRATIZE ALGORITHMIC GOVERNANCE?}

Arne Hintz

Cardiff University

Citizens are increasingly assessed, profiled and categorized according to data assemblages. Government and public sector institutions are using data analytics to rate and rank citizens, households and communities and allocate services accordingly (Eubanks 2018, Yeung 2018). Data scores are emerging as prominent mechanism for government institutions to focus social services and interventions, guide policing, regulate people's movements, and affect people's well-being and living conditions (Citron and Pasquale 2014, Dencik et al 2019). Increasingly, state-citizen relations are thus affected by algorithmic decision-making.

Yet this happens largely without people's knowledge and without avenues to meaningfully engage and intervene. While citizens become infinitely knowable, they have little ability to interrogate and challenge the use of their data. This raises significant challenges for democratic processes, active citizenship and public participation (Hintz et al 2019). How, then, do we participate as citizens in a society in which we are assessed and categorized according to data analytics which we do not understand? How do we intervene into algorithmic governance processes and affect the development and management of the very data systems that increasingly organize society? How do we develop new democratic practices to ensure participation, transparency and accountability?

Citizen assemblies, citizen juries, deliberative polls and other models of public engagement and deliberation offer opportunities for advancing citizen voices outside and beyond classic electoral procedures. While distinct in their specific implementation (i.e., their size, goals, policy focus, etc.), they share an approach of bringing together a

Suggested Citation (APA): Hintz, A. (2021, October). Towards Civic Participation in the Datafied Society: Can Citizen Assemblies Democratize Algorithmic Governance? Paper presented at AoIR 2021: The 22nd Annual Conference of the Association of Internet Researchers. Virtual Event: AolR. Retrieved from http://spir.aoir.org. 
small selection of the population for deliberation on key issues that society is facing (Smith 2009; Escobar \& Elstub 2017). They have successfully been applied to discuss problems and develop shared norms and policy solutions across a growing range of thematic areas (OECD 2020).

Those areas have expanded to questions of data and AI. In the UK, the geographic focus of this study, participatory and deliberative events have included (in the past two years alone) a citizens jury on the use of automated decision-making, a citizens' summit on the use of data in the health and care sector, citizens juries on applications of $\mathrm{Al}$ in criminal justice, recruitment and healthcare, and a citizens' biometrics council on the use of facial recognition technology. Several of these initiatives were commissioned by major oversight and advisory institutions, such as the Royal Society and the Information Commissioners Office, and are thus closely related to policy development.

As part of a larger project on 'Civic Participation in the Scoring Society', based at the Data Justice Lab at Cardiff University, we have examined different practices for enhancing civic engagement with data analytics. The part of the project that is discussed in this paper draws on findings from 15 expert interviews conducted between June 2019 and March 2021 with members of government, civil society organizations and providers of citizen engagement fora; extensive desk research on methods and cases of participatory initiatives; and a fact-finding workshop with representatives of relevant institutions and initiatives. We have been interested in the level of participation, the decision-making power and the policy impact of public engagement initiatives, as well as prospects for institutionalizing civic participation at different levels of decisionmaking.

Conceptually, the study is situated at the intersection of two different areas of research that have rarely been in detailed conversation - critical data studies and democratic innovation. Critical data studies has explored the role of data in a wide range of social settings (e.g., boyd and Crawford 2012, Kitchin 2014) as well as in government and the public sector (e.g., Dencik et al 2019), while work on democratic innovation has advanced our knowledge of participatory mechanisms but has not focused on the specific challenges of communication technologies (e.g., Goodin 2008, Patriquin 2020). Some insights from participatory studies have been applied to the field of media and communication (see Carpentier 2011) but have not yet been systematically adopted for algorithmic governance. Most prominently, attempts of auditing algorithms and data systems have been explored (e.g., Kitchin 2017, O’Neil 2016, Reisman et al. 2018) but often remain in a technology-centred and expert-based context that has limitations in advancing broader societal deliberation and participation.

Our research on the suitability of models of civic engagement for decisions on the deployment of data analytics systems suggests that citizen assemblies, citizen juries and similar initiatives can be a useful tool in larger strategies for democratizing the datafied state but have several limitations. They can raise public knowledge and awareness, they demonstrate that citizens can address complex problems of datafication, and they can lead to policy change if they are closely related to a specific policymaking process. However, in order to have policy impact and fulfil their substantial resource requirements, they are often commissioned and guided by larger institutional 
actors (government, think tanks, public opinion institutes), rather than self-organised by citizens or social movements, which limits both the range of issues discussed and the freedom of participants to challenge dominant views about data. While very few of these initiatives could be characterized as mere 'engagement-washing' exercises, the tradeoff between policy effectiveness and fundamental re-thinking of the datafied society constitutes a tension at the core of these mechanisms. A more detailed discussion of the research findings will be provided in an upcoming research report that will be available on the Data Justice Lab website (https://datajusticelab.org).

Despite their shortcomings, models of public engagement and democratic innovation demonstrate a growing concern with the democratic deficiencies of algorithmic governance and offer significant starting-points for expanding democratic practices in a datafied society and placing datafication under public control.

\section{References}

boyd, d. \& Crawford, K. (2012). Critical Questions for Big Data. Information, Communication \& Society, 15(5).

Carpentier, N. (2011). Media and Participation. Bristol: Intellect.

Citron, D. K. and Pasquale, F. (2014). The Scored Society: Due Process for Automated Predictions. Washington Law Review, 89(1).

Dencik, L., Redden, J., Hintz, A. and Warren, H. (2019). The golden view: data-driven governance in the scoring society. Internet Policy Review, 8(2).

Escobar. O. and Elstub, S. (2017). Forms of Mini-Publics: An introduction to deliberative innovations in democratic practice. New Democracy Foundation.

Eubanks, V. (2018). Automating Inequality: How High-Tech Tools Profile, Police, and Punish the Poor. St. Martin's Press.

Goodin, R.E. (2008). Innovating Democracy: Democratic Theory and Practice After the Deliberative Turn. Oxford: Oxford University Press.

Hintz, A., Dencik, L., and Wahl-Jorgensen, K. (2019). Digital Citizenship in a Datafied Society. Polity Press. 
Kitchin, Rob (2014). The Data Revolution: Big Data, Open Data, Data Infrastructures \& Their Consequences, London: Sage.

Kitchin, R. (2017). Thinking critically about and researching algorithms. Information, Communication and Society 20(1).

OECD (2020) Innovative Citizen Participation and New Democratic Institutions. Report.

O'Neil, C. (2016). Weapons of Math Destruction: How Big Data Increases Inequality and Threatens Democracy. New York: Crown Random House.

Patriquin, L. (2020). Permanent Citizens' Assemblies: A new model for public deliberation. London/New York: Rowman and Littlefield International.

Reisman et al. (2018). Algorithmic Impact Assessments: A Practical Framework for Public Agency Accountability. Report of the AINOW Institute. Available at: https://ainowinstitute.org/aiareport2018.pdf

Smith, G. (2009). Democratic Innovations. Cambridge University Press.

Yeung, K. (2018). Big Data-driven Government: Towards a New Public Analytics in Public Administration? Paper presented at ICON-S, Hong Kong, May 27 